\title{
The effect of age, genotype and sex on carcass traits, meat quality and sensory attributes of geese
}

\author{
Linda Uhlířová1,2 , ${ }^{1}$, Eva Tůmová', Darina Chodová1, Jana Vlčkováa,2, Mohamed Ketta1, \\ Zdeněk Volek ${ }^{2}$, and Věra Skřivanová ${ }^{2}$
}

* Corresponding Author: Linda Uhliřová
Tel: +42-0-267-009-748, Fax: + 42-0-267-710-779,
E-mail: uhlirova.linda@vuzv.cz

1 Department of Animal Husbandry, Czech University of Life Sciences Prague, 16521 Prague - Suchdol, Czech Republic

2 Department of Physiology of Nutrition and Product Quality, Institute of Animal Science, 10400 Prague Uhřinèves, Czech Republic

ORCID

Linda Uhliŕová

https://orcid.org/0000-0001-7186-3581

Eva Tủmová

https://orcid.org/0000-0001-6634-1308

Darina Chodová

https://orcid.org/0000-0003-0107-9657 Jana Vlčková

https://orcid.org/0000-0001-8024-2920

Mohamed Ketta

https://orcid.org/0000-0003-0264-0581

Zdeněk Volek

https://orcid.org/0000-0002-3655-2726

Věra Skřivanová

https://orcid.org/0000-0002-3064-4806

Submitted Mar 13, 2017; Revised Jun 3, 2017; Accepted Jul 28, 2017
Objective: The aim of this study was to compare carcass traits, meat quality and sensory attributes in two different genotypes of geese according to age and sex.

Methods: The experiment was carried out on 160 birds of two genotypes of geese: the Czech Goose (CG) breed and a Eskildsen Schwer (ES) hybrid. One-d-old goslings were divided into four groups according to genotype and sex. Two dates for slaughtering (at 8 and 16 wk of age of goslings) were undertaken.

Results: The slaughter weight, cold carcass weight and dressing percentage were affected by all the studied factors, and significant interactions between age, genotype and sex were detected in the slaughter weight ( $\mathrm{p}<0.001)$ and cold carcass weight $(\mathrm{p}=0.004)$. The $\mathrm{pH}$ was not affected by any of studied factors, whereas in terms of meat colour parameters there were observed significant effects of age on $\mathrm{L}^{*}$ and $\mathrm{b}^{*}$ value and a significant effect of sex on $\mathrm{a}^{*}$ value. The meat fat content was higher $(\mathrm{p}=0.002)$ in ES. Higher score for overall acceptance of goose meat was recorded for ES at both ages compared to CG.

Conclusion: ES had higher dressing percentage and better sensory attributes, whereas CG exceled in the favourable nutritional value of the meat.

Keywords: Age; Carcass Traits; Genotype; Meat Quality; Sensory Attributes; Sex

\section{INTRODUCTION}

In recent years, the demand for poultry meat with taste that differs from that of broiler chickens has increased among consumers [1]. Similarly, consumers look for high-quality meat in terms of human health. Among the various alternative poultry species, geese have interesting biological characteristics; such as a high juvenile growth rate, a good adaptation to free range and grazing, disease resistance and a high dietary meat quality [2].

Geese rearing has a long tradition in Europe and Asia. Over time special hybrids have been bred for intensive meat production system. However, in recent years, attention has focused again on the meat production of native breeds of geese $[3,4,1,5]$. These breeds of geese are characterized by good musculature and low carcass fatness, as well as high dressing percentage [6].

Poultry meat quality results from complex interactions between the genotype of the animal and its environment [7]. The carcass composition varies during the fattening period. The cold carcass weight increase until 16 weeks, and the dressing percentage steadily increase from 2 to 8 weeks. The growth of the breast and thighs differs greatly compared with each other [8]. A different carcass composition also exists among the various genotypes of geese [9]. Hybrid geese have a higher slaughter weight, carcass weight and dressing percentage than native breeds of geese [1]. The effect of sex on carcass traits is expressed by a signifi- 
cantly higher weight of the carcass and its individual parts in males [3,1].

Regarding meat physical properties, the ultimate $\mathrm{pH}$ has great importance in the evaluation of meat quality, because it may directly affect other quality characteristics; such as meat colour parameters and shear force [4]. In terms of the nutritional value of the meat, goose meat is characterized by low intramuscular fat content with relatively high levels of unsaturated fatty acids and low cholesterol [10]. Isguzar and Pingel [9] found different contents of protein and fat in various local Turkish breeds of geese. A study by Wężyk et al [11] showed significant differences in the ash content between two hybrid geese strains. Liu et al [12] observed the effect of sex on the water and protein contents of goose meat.

The sensory attributes of meat are important factors that determine consumer preference for a product. From this perspective, limited information exists about goose meat. Hamadani et al [2] compared goose meat with chicken meat and mutton for selected sensory characteristics. They showed that consumers highly preferred goose meat to chicken meat or mutton in terms of appearance, texture, taste and overall acceptability. Geldenhuys et al [13] conducted a study, which evaluated the sensory characteristics of Egyptian Goose meat with meat of other poultry species, and observed that Egyptian Goose meat had a strong game aroma and game flavour and was low in tenderness and juiciness.

The aim of this study was to compare carcass traits, meat quality and sensory properties in the traditional Czech Goose breed and and Eskildsen Schwer hybrid goose according to age and sex.

\section{MATERIALS AND METHODS}

All experimental protocols were approved by the Czech University of Life Sciences Prague, Faculty of Agrobiology, Food and Natural Resources of the Czech Republic and Institutional and National Committees.

\section{Birds and design of experiment}

The experiment was carried out on a total of 160 geese: 40 males and 40 females of the Czech Goose (CG) breed and 40 males and 40 females of the crossbreed Eskildsen Schwer (ES). One-d-old goslings were weighed and divided into four groups according to genotype and sex. Goslings were housed in littered pens (20 goslings per pen), the floor space was six birds per $\mathrm{m} 2$. The daily photoperiod was as follows: $24 \mathrm{~h}$ light for the first three days of fattening period, then it was changed to $16 \mathrm{~h}$ light and $8 \mathrm{~h}$ darkness between 4 th and 7 th day of the fattening period, and from the 8th day the photoperiod consisted of $14 \mathrm{~h}$ light and $10 \mathrm{~h}$ darkness. Goslings had ad libitum access to water and feedstuff; the feed mixture VH1 IT was fed until the goslings were $4 \mathrm{wk}$ of age, and the feed mixture
VH2 IT until the goslings were $16 \mathrm{wk}$ of age. The ingredient and chemical composition of feed mixtures is shown in Table 1.

Two dates for slaughtering were undertaken to evaluate the effect of age on carcass traits, meat quality and sensory evaluation: the first for goslings at $8 \mathrm{wk}$ of age, and the second for goslings at 16 wk of age. Both slaughterings were performed under the same conditions. Eight birds of average body weight in each group (4 from each pen; total of 32) were slaughtered by cutting the carotid arteries and then were immediately bled. The heads and feet were removed, and the carcasses were then eviscerated and, after $24 \mathrm{~h}$ of chilling at $4^{\circ} \mathrm{C}$, weighed to obtain the cold carcass weight. The abdominal fat, breast muscle and thighs were removed and weighed separately. Thighs were then deboned to obtain the weights of thigh muscle. The dressing percentage was calculated as the percentage of cold carcass weight from slaughter weight. The percentages of breast muscle, thighs, thigh muscle and abdominal fat were calculated as a percentage of the cold carcass weight.

\section{Measurement of meat physical properties}

The $\mathrm{pH}$ value was measured $24 \mathrm{~h}$ post mortem using a Jenway pH Meter (Jenway, Essex, England) with a glass probe introduced one $\mathrm{cm}$ deep into the transversal section of the Pectoralis major muscle. Meat colour parameters were detected on a transversal section of the Pectoralis major muscle $24 \mathrm{~h}$ post-mortem using Minolta SpectraMagic NX analyser (Konica Minolta Sensing, Inc., Osaka, Japan) with the CIELab System [14]. Meat colour was expressed as $\mathrm{L}^{*}$ (lightness), $\mathrm{a}^{*}$ (redness), and $\mathrm{b}^{*}$ (yellowness) values.

Meat texture was determined by the Warner-Bratzler shear test in the Pectoralis major muscle. Twenty four h after slaughtering breast muscle samples were frozen to $-20^{\circ} \mathrm{C}$, and later

Table 1. Ingredient and chemical compositions of feed mixtures

\begin{tabular}{lcc}
\hline & VH 1 & VH 2 \\
\hline Ingredients (\%) & 36.50 & 27.45 \\
Wheat & 23.00 & 40.00 \\
$\quad$ Maize & 29.00 & 20.00 \\
Soybean meal & 3.50 & 4.00 \\
Meatbone meal & 2.00 & - \\
Fish meal & 2.00 & 4.00 \\
Fat & 0.30 & 0.15 \\
Met (40\%) & 0.20 & - \\
Lys (40\%) & 1.00 & 1.00 \\
Vitamin premix & 1.00 & 1.30 \\
Dicalcium phosphate & 0.30 & 0.40 \\
Salt & 1.20 & 1.70 \\
Limestone & & \\
Chemical composition & 24.80 & 17.89 \\
Crude protein (\%) & 11.50 & 12.77 \\
Metabolizable energy (MJ/kg) & & \\
\hline
\end{tabular}

Met, methionine; Lys, lysine. 
defrosted at $4^{\circ} \mathrm{C}$ for $24 \mathrm{~h}$. Samples were packaged in plastic bags with zip ties and were heated in a water bath at $75^{\circ} \mathrm{C}$ for $1 \mathrm{~h}$. Meat samples were then cut into $2 \times 1 \mathrm{~cm} 2$ cubes with the cuts running parallel to the muscle fibres. Tenderness was measured using a texturometer Instron Model 3342 (Instron, Norwood, MA, USA) with a Warner-Bratzler shear blade with a triangular hole. The load cell was $20 \mathrm{~N}$ with a crosshead speed of $100 \mathrm{~mm} / \mathrm{min}$ and a sampling rate of 20 points/s. The maximum shear force $(\mathrm{N})$ was determined. In addition to tenderness, the cooking loss was calculated from the difference between the weights of the raw and cooked meat.

\section{Analysis of chemical composition of meat}

Chemical meat composition was determined in the left thigh muscle according to procedures of AOAC International [15]. The moisture content (\%) of the meat was analysed by drying in an oven at $105^{\circ} \mathrm{C}$ (procedure 934.01), and crude fat content (\%) was obtained by extraction with petroleum ether in a Soxtec 1043 apparatus (procedure 920.39; FOS Tecator AB, Högänas, Sweden). The crude protein content (\%) in the meat was determined using a Kjeltec Auto 1030 Analyser (procedure 954.01; FOS Tecator AB, Sweden). The crude ash content (\%) was detected according to procedure 920.15. Hydroxyproline was determined by acid hydrolysis according to Diemar [16]. The energy value of the meat was calculated using an equation based on the protein and fat content in the meat. The equation [17] is given below.

Energetic value $(\mathrm{MJ} / \mathrm{kg})$

$=[(16.74 \times$ protein content $)+(37.66 \times$ fat content $)] / 1,000$

\section{Sensory evaluation}

The evaluation of meat sensory attributes was conducted in two dates, following each of slaughterings, on the breast muscles from 8 birds of each group. Samples for sensory analysis were vacuum-packed and stored for $5 \mathrm{~d}$ after dissection at approximately $4^{\circ} \mathrm{C}$. After storage, the samples were tagged with codes and boiled in water in a closed container for $150 \mathrm{~min}$ without salt or other seasoning. Sensory characteristics were evaluated by 10 panelists trained by the methods according to ISO 8586-1 [18]. The analysis took place in special sensory laboratory with 10 individual booths under controlled environmental conditions and red light to obscure meat colour [19]. Each panelist received a set of four samples at $50^{\circ} \mathrm{C}$ : one sample of each experimental group. There was a 10-min interval between serving each set of samples. Water at room temperature and fresh bread were provided to panelists to neutralize their sensory percepts. The panelists scored odour intensity and preference, flavour intensity and preference, tenderness, juiciness and overall acceptance using a 9-point scale (1, low; 9 , high). The methodology of sensory analysis was based on the methodology described by Tůmová et al [20], with mod- ifications for poultry meat.

\section{Statistical analyses}

The data were processed with SAS software [21]. The results of the carcass traits, meat physical properties and chemical composition of meat were analysed by a three-way analysis of variance with the interaction of age, genotype and sex (general linear model procedure). Age, genotype and sex were considered as fixed effects. Differences between means with $p<0.05$ were accepted as statistically significant and tested by the Scheffé test.

The results of the sensory evaluation were calculated (for each of the terms separately) by a two-way analysis of variance, and mixed linear model (MIXED procedure) was used. The model included the fixed effects of genotype and sex and their interaction, and random effect of panelist. Differences between means with $\mathrm{p}<0.05$ were considered as statistically significant and examined by the Tukey test. For all statistical analyses the individual bird was the experimental unit.

\section{RESULTS}

\section{Carcass traits}

The results of the carcass traits are presented in Table 2. Slaughter weight, cold carcass weight and dressing percentage were affected by all observed factors. Significant interaction effects were noted among the age, genotype and $\operatorname{sex}(\mathrm{p}<0.001)$, between the age and sex $(\mathrm{p}<0.001)$ and between the genotype and sex $(\mathrm{p}<0.001)$ in the slaughter weight. For the cold carcass weight, interactions were observed among the age, genotype, and sex $(\mathrm{p}=0.004)$ and between the age and sex $(\mathrm{p}=0.012)$. An interaction between the age and sex $(p=0.030)$ was only detected in the dressing percentage. The highest slaughter weight, cold carcass weight and dressing percentage were observed in 16-wk-old ES males, and the lowest in 8-wk-old CG females. The breast muscle percentage and the thigh percentage were significantly affected only by age. The breast muscle percentage increased with age, whereas thigh percentage decreased with age. Moreover, for breast muscle percentage the interaction between the age and genotype $(\mathrm{p}<0.001)$ was significant. The thigh muscle percentage and the abdominal fat percentage were influenced significantly by the age and genotype.

\section{Meat physical properties}

The results of the physical properties of the meat are described in Table 3. The $\mathrm{pH}$ value of the breast meat was not affected by any of the studied factors. Meat colour parameters $L^{*}(p<0.001)$ and $b^{*}(p=0.005)$ were significantly affected by age, with higher values in the 8 -wk-old geese, whereas $\mathrm{a}^{*}$ value was significantly $(p<0.001)$ affected by sex, with higher values in males. Shear force value of breast meat was affected only by age $(\mathrm{p}<0.001)$ 
Table 2. Carcass traits in geese as affected by age, genotype and sex

\begin{tabular}{|c|c|c|c|c|c|c|c|c|c|}
\hline Age/genotype/sex & & & SW (g) & CCW (g) & DP (\%) & BMP (\%) & TP (\%) & TMP (\%) & AFP (\%) \\
\hline \multirow[t]{4}{*}{$8 w k$} & Eskildsen Schwer & $\hat{0}$ & $5,113^{c}$ & $3,368^{c}$ & 71.9 & 12.1 & 20.6 & 13.5 & 3.5 \\
\hline & & o & $4,710^{d}$ & $2,876^{d}$ & 66.8 & 14.4 & 21.2 & 13.7 & 4.2 \\
\hline & Czech Goose & $\hat{\sigma}$ & $3,658^{\dagger}$ & $2,166^{e}$ & 65.5 & 12.4 & 22.6 & 14.8 & 3.6 \\
\hline & & 우 & $3,265^{9}$ & $1,854^{e}$ & 64.4 & 12.2 & 22.1 & 15.9 & 3.6 \\
\hline \multirow[t]{4}{*}{16 wk } & Eskildsen Schwer & $\hat{o}$ & $6,550^{\mathrm{a}}$ & $4,410^{a}$ & 72.1 & 15.8 & 15.8 & 9.5 & 3.8 \\
\hline & & o & $5,899^{b}$ & $3,955^{b}$ & 71.8 & 15.8 & 17.1 & 9.6 & 3.2 \\
\hline & Czech Goose & $\hat{\delta}$ & $5,349^{c}$ & $3,449^{c}$ & 70.0 & 17.4 & 17.7 & 11.0 & 3.0 \\
\hline & & 우 & $4,119^{e}$ & $2,652^{d}$ & 70.1 & 17.6 & 17.5 & 11.2 & 2.9 \\
\hline RMSE & & & 149 & 172 & 2.7 & 1.4 & 1.6 & 1.2 & 0.8 \\
\hline Age & & & $<0.001$ & $<0.001$ & $<0.001$ & $<0.001$ & $<0.001$ & $<0.001$ & 0.018 \\
\hline Genotype & & & $<0.001$ & $<0.001$ & $<0.001$ & 0.340 & 0.002 & $<0.001$ & 0.046 \\
\hline Sex & & & $<0.001$ & $<0.001$ & 0.022 & 0.096 & 0.460 & 0.171 & 0.872 \\
\hline Age $\times$ genotype & & & 0.588 & 0.816 & 0.069 & $<0.001$ & 0.604 & 0.746 & 0.386 \\
\hline Age $\times$ sex & & & $<0.001$ & 0.012 & 0.030 & 0.199 & 0.543 & 0.379 & 0.070 \\
\hline Genotype $\times$ sex & & & $<0.001$ & 0.346 & 0.123 & 0.121 & 0.110 & 0.434 & 0.799 \\
\hline Age $\times$ genotype $\times$ sex & & & $<0.001$ & 0.004 & 0.193 & 0.066 & 0.839 & 0.508 & 0.163 \\
\hline
\end{tabular}

SW, slaughter weight; CCW, cold carcass weight; DP, dressing percentage; BMP, breast muscle percentage; TP, thigh percentage; TMP, thigh muscles percentage; AFP, abdominal fat percentage; RMSE, root mean square error.

${ }_{a, \mathrm{f}}$ Means in the same column with no common superscript differ $(p<0.05)$.

and significant interactions between age and genotype ( $\mathrm{p}=$ $0.009)$, age and $\operatorname{sex}(\mathrm{p}=0.016)$ and genotype and $\operatorname{sex}(\mathrm{p}<0.001)$ were detected. The highest value of shear force was observed in 16-wk-old CG males, and the lowest in 8-wk-old CG females. For the cooking loss of breast meat, main effects of age $(\mathrm{p}<0.001)$ and genotype $(\mathrm{p}=0.011)$ and interaction effect between the genotype and $\operatorname{sex}(\mathrm{p}<0.001)$ were detected.

\section{Chemical composition of meat}

Table 4 shows the results of the chemical composition of the goose meat. Moisture content was significantly affected by age and interaction effects were between the age and genotype $(\mathrm{p}<0.001)$, the age and sex $(\mathrm{p}=0.016)$ and the genotype and sex $(p=0.007)$. Crude fat content and energy value of meat were affected by the age $(\mathrm{p}<0.001)$ and genotype, and a significant interaction effects were between the age and genotype $(\mathrm{p}<0.001)$ and age and sex. Regarding crude protein content in meat, sex was found to have a significant effect and an in-

Table 3. pH value, colour parameters, shear force and cooking loss of musculus pectoralis major measured $24 \mathrm{~h}$ after slaughtering in geese as affected by age, genotype, and sex

\begin{tabular}{|c|c|c|c|c|c|c|c|c|}
\hline \multirow{2}{*}{ Age/genotype/sex } & & & \multirow{2}{*}{$\mathrm{pH}$} & \multicolumn{3}{|c|}{ Colour } & \multirow{2}{*}{ Shear force (N) } & \multirow{2}{*}{ Cooking loss (\%) } \\
\hline & & & & $L^{*}$ & $a^{*}$ & $b^{*}$ & & \\
\hline \multirow[t]{4}{*}{$8 w k$} & Eskildsen Schwer & $\hat{0}$ & 5.76 & 45.94 & 13.62 & 14.17 & 34.37 & 39.52 \\
\hline & & q & 5.77 & 46.47 & 11.09 & 11.92 & 42.86 & 38.34 \\
\hline & Czech Goose & $\hat{o}$ & 5.71 & 43.01 & 12.27 & 11.05 & 33.49 & 38.97 \\
\hline & & q & 5.78 & 45.31 & 11.12 & 11.41 & 33.41 & 40.42 \\
\hline \multirow[t]{4}{*}{$16 w k$} & Eskildsen Schwer & $\hat{\sigma}$ & 5.84 & 38.92 & 14.50 & 10.82 & 42.05 & 35.73 \\
\hline & & q & 5.93 & 36.87 & 12.16 & 10.15 & 39.22 & 33.65 \\
\hline & Czech Goose & $\hat{\sigma}$ & 5.71 & 37.93 & 13.48 & 10.36 & 48.12 & 36.86 \\
\hline & & $q$ & 5.70 & 35.85 & 10.53 & 10.44 & 38.92 & 37.14 \\
\hline RMSE & & & 0.21 & 5.46 & 2.57 & 2.45 & 11.28 & 1.46 \\
\hline Age & & & 0.468 & $<0.001$ & 0.324 & 0.005 & $<0.001$ & $<0.001$ \\
\hline Genotype & & & 0.067 & 0.268 & 0.127 & 0.127 & 0.726 & 0.011 \\
\hline Sex & & & 0.428 & 0.814 & $<0.001$ & 0.322 & 0.313 & 0.603 \\
\hline Age $\times$ genotype & & & 0.148 & 0.589 & 0.576 & 0.136 & 0.009 & 0.053 \\
\hline Age $\times$ sex & & & 0.964 & 0.074 & 0.499 & 0.566 & 0.016 & 0.126 \\
\hline Genotype × sex & & & 0.927 & 0.646 & 0.746 & 0.147 & $<0.001$ & $<0.001$ \\
\hline Age $\times$ genotype $\times$ sex & & & 0.495 & 0.638 & 0.404 & 0.418 & 0.718 & 0.754 \\
\hline
\end{tabular}

RMSE, root mean square error. 
Table 4. Chemical composition of goose meat as affected by age, genotype and sex

\begin{tabular}{|c|c|c|c|c|c|c|c|c|}
\hline \multirow[t]{3}{*}{$8 w k$} & Eskildsen Schwer & $\hat{0}$ & 75.95 & 2.02 & 20.62 & 1.14 & 0.10 & 4.21 \\
\hline & Czech Goose & $\hat{0}$ & 75.22 & 2.46 & 20.93 & 1.12 & 0.12 & 4.43 \\
\hline & & q & 75.54 & 2.54 & 20.50 & 1.12 & 0.12 & 4.39 \\
\hline \multirow[t]{3}{*}{16 wk } & Eskildsen Schwer & $\hat{0}$ & 74.29 & 3.94 & 20.51 & 1.10 & 0.11 & 4.91 \\
\hline & Czech Goose & $\hat{0}$ & 74.80 & 2.94 & 20.72 & 1.11 & 0.12 & 4.57 \\
\hline & & q & 75.40 & 2.87 & 20.25 & 1.09 & 0.11 & 4.47 \\
\hline RMSE & & & 0.46 & 0.45 & 0.32 & 0.04 & 0.01 & 0.16 \\
\hline Age & & & $<0.001$ & $<0.001$ & 0.056 & 0.002 & 0.463 & $<0.001$ \\
\hline Genotype & & & 0.069 & 0.002 & 0.643 & 0.050 & $<0.001$ & 0.003 \\
\hline Age $\times$ genotype $\times$ sex & & & 0.194 & 0.109 & 0.776 & 0.438 & 0.766 & 0.111 \\
\hline
\end{tabular}

Hyp, hydroxyproline; RMSE, root mean square error.

teraction effect between the genotype and $\operatorname{sex}(\mathrm{p}=0.006)$ was found for the same parameter. The crude ash content was significantly affected by the age $(\mathrm{p}=0.002)$ and genotype $(\mathrm{p}=$ 0.050 ). The hydroxyprolin content was influenced only by genotype $(\mathrm{p}<0.001)$, with higher values observed in CG.

\section{Sensory attributes of meat}

Table 5 presents the results of sensory attributes of goose meat. In terms of evaluation at the age of $8 \mathrm{wk}$ of geese, genotype affected significantly all sensory traits except odour intensity and flavour intensity. In this respect, better scores were detected in ES. A significant effect of sex was observed on tenderness, flavour intensity and preference and overall acceptance, where females scored better. An interaction ( $\mathrm{p}=0.011)$ effect between genotype and sex was noted on tenderness.

In 16-wk-old geese odour preference, tenderness, flavour preference and overall acceptance were significantly influenced by genotype, all of these traits were scored better in ES. Sex af-

Table 5. Meat sensory attributes in geese at the age of 8 and 16 wk depending on genotype and sex

\begin{tabular}{|c|c|c|c|c|c|c|c|c|}
\hline Genotype/sex & & Ol & $\mathrm{OP}$ & $\mathrm{T}$ & J & $\mathrm{FI}$ & $\mathrm{FP}$ & $O A$ \\
\hline \multicolumn{9}{|c|}{ 1st term of evaluation, 8-wk-old geese } \\
\hline Eskildsen Schwer & $\hat{o}$ & 6.44 & 6.29 & $6.00^{\mathrm{a}}$ & 5.29 & 6.30 & 6.38 & 6.13 \\
\hline \multirow[t]{2}{*}{ Czech Goose } & $\hat{o}$ & 6.16 & 6.02 & $5.40^{\mathrm{b}}$ & 4.95 & 6.11 & 5.77 & 5.42 \\
\hline & o & 6.01 & 5.80 & $6.20^{\mathrm{a}}$ & 5.09 & 6.52 & 6.01 & 5.76 \\
\hline SEM & & 0.286 & 0.302 & 0.286 & 0.294 & 0.211 & 0.251 & 0.266 \\
\hline Genotype $\times$ sex & & 0.666 & 0.354 & 0.011 & 0.992 & 0.299 & 0.624 & 0.496 \\
\hline \multicolumn{9}{|c|}{ 2nd term of evaluation, 16 -wk-old geese } \\
\hline \multirow[t]{2}{*}{ Eskildsen Schwer } & $\hat{0}$ & 6.33 & $6.15^{\mathrm{ab}}$ & $6.23^{\mathrm{a}}$ & $5.67^{\mathrm{a}}$ & 6.35 & 6.40 & 6.37 \\
\hline & o & 6.21 & $6.39^{\mathrm{a}}$ & $6.13^{\mathrm{a}}$ & $5.36^{\mathrm{ab}}$ & 6.50 & 6.76 & 6.41 \\
\hline Czech Goose & $\hat{o}$ & 6.20 & $6.15^{\mathrm{ab}}$ & $5.34^{b}$ & $5.08^{b}$ & 6.00 & 5.76 & 5.46 \\
\hline Sex & & 0.373 & 0.479 & 0.076 & 0.308 & 0.007 & 0.058 & 0.129 \\
\hline Genotype × sex & & 0.809 & 0.043 & 0.025 & 0.007 & 0.074 & 0.733 & 0.205 \\
\hline
\end{tabular}

Ol, odour intensity; OP, odour pleasantness; $\mathrm{T}$, tenderness; J, juiciness; FI, flavour intensity; FP, flavour pleasantness; OA, overalll acceptance; SEM, standard error of mean.

$a, b$ Means in the same column with no common superscript differ $(p<0.05)$. 
fected significantly only flavour intensity, which was more intensive in female than in males. Interactions between genotype and sex were detected in odour preference $(\mathrm{p}=0.043)$, tenderness $(\mathrm{p}=0.025)$, and juiciness $(\mathrm{p}=0.007)$.

\section{DISCUSSION}

The carcass characteristics in both genotypes were significantly affected by age. The 16-wk-old geese had approximately a 30\% higher live weight, a $40 \%$ higher cold carcass weight and a $4 \%$ higher dressing percentage than the 8 -wk-old geese. Tilki et al [8] stated that, at the age of $9 \mathrm{wk}$, geese have actually achieved only $70 \%$ to $80 \%$ of their adult weight. Breast meat percentage was approximately $4 \%$ higher in the older geese, whereas the thigh meat percentage decreased with the age. The results correspond with those of Tilki et al [8], who reported that these differences are caused by disparities in the growth of these parts. These authors also state that thighs reach their final proportion at the age of $10 \mathrm{wk}$, whereas the intensive growth of breast continues until $16 \mathrm{wk}$ of age. Genotype and sex had an impact on cold carcass weight and dressing percentage, which were significantly higher in the hybrid geese than in the CG. Regarding sex effects, males had higher carcass weight and dressing percentage. Similar results were observed by Kapkowska et al [1], who compared the fattening results of White Koluda hybrid and traditional breed Zatorska according to sex. However, Saatci et al [3] and Buzała et al [10] found a higher dressing percentage in females. The results of the present experiment revealed a significant interaction effect of age and sex in the dressing percentage. The dressing percentage was affected by interaction between genotype and sex in both slaughtering times. This interaction effect shows sex differences in the measurements at 8 and $16 \mathrm{wk}$ of age, whereas in CG dressing percentage in males and females did not differ. Abdominal fat percentage was significantly affected by the age and genotype, with higher values in the 8-wk-old ES birds. Compared to the results of Saatci et al [3] and Hamadani et al [2], who recorded a higher abdominal fat percentage in females, in the present study, the effect of sex was not significant. This disproportion is assumed to be related to the genotype.

In the present experiment, the $\mathrm{pH}$ of the breast meat when measured $24 \mathrm{~h}$ post-mortem was not affected by age, genotype or sex. However, Kirmizibayrak et al [4] detected significantly higher ultimate $\mathrm{pH}$ of the breast muscles in females. Generally, differences in $\mathrm{pH}$ values could be explained by differences in the glycogen reserves at slaughter, responses to preslaughter stress or slaughter weight. Meat colour is an important characteristic of meat quality used to assess the freshness and quality of meat by consumers and is closely related to the ultimate $\mathrm{pH}$. Abdullah et al [22] observed a lower $\mathrm{L}^{*}$ value in the breast meat of broilers at 32 days of age than in 42-day-old chickens, and they explained that these differences are related to a lower ultimate $\mathrm{pH}$ in the breast of older chickens. Based on this finding, a slightly lower $\mathrm{pH}$ value of the meat of 8 -wk-old geese could lead to a higher $\mathrm{L}^{*}$ value compared to the meat of 16 -wkold geese. Contrary to our results, Kirmizibayrak et al [4] did not find a significant effect of age on the $\mathrm{L}^{*}$ parameter. However, consistent with our study, they detected an effect of sex on redness. Regarding shear force, in the present experiment, a greater force had to be applied to cut muscles in the older geese than in the younger ones. This could be related to the development of the muscle tissue, because cross-sectional area of muscle fibre increases with age [23]. In 8-wk-old geese, the muscle tissue probably consists of a higher number of muscle fibres with a smaller cross-sectional area, and the meat could therefore be tenderer than in the 16-wk-old geese. Contrary to our results, Kirmizibayrak et al [4] and Jassim et al [24] did not find an effect of age on the instrumental meat tenderness. The results of cooking loss in the present study are similar to those of Baeza et al [25], who also detected that cooking loss decreased with age. Moreover, in contrast with other studies $[11,1]$, we also observed significant effect of genotype on the cooking loss. Differences in cooking loss with respect to age or genotype might be attributed to different proteins solubility (especially collagen) and to different fat content. Cooking temperature and ultimate $\mathrm{pH}$ could also play a role.

The chemical composition of goose meat was affected mainly by age and genotype. Few data were found in the literature about the effect of age chemical composition of goose meat. Baeza et al [25] observed a significantly lower water content and higher lipid content in 11-wk-old ducks than in 8-wk-old ducks. This trend is very similar to the results of our study and is because the lipid content of the breast increases with age at the expense of the water content. Okruszek et al [5] observed significantly different fat content between two native polish goose breeds. When compared the meat fat content of the White Koluda hybrid strains [11] to the fat content of the traditional goose breeds [5], lower values were detected in traditional breeds of geese. The results of our study are in agreement with this finding. This difference occurs because hybrid geese are bred for intensive meat production and thus grow faster and reach the inflection point earlier than traditional goose breeds. The results for the protein content are in agreement with those of Liu et al [12], who also detected a higher protein content in males. Regarding hydroxyproline content, we observed higher values in the CG. However, no information is available in the literature about the effect of genotype on hydroxyproline content in poultry meat. For pork meat, a clear influence of genotype on hydroxylysylpyridinoline has been described by Maiorano et al [26]. Higher hydroxyproline content in CG could lead to lower tenderness of the CG meat during sensory analysis.

Sensory evaluation is a useful tool for quality assessment of the various foods, including meat. In the present study, the 
mean score for all sensory attributes varied between values 5 to 7 for both genotypes of geese for both ages evaluated. Hamadani et al [2] recorded a similar score (6+) in all observed sensory attributes, but different methodology was used. Regarding the effect of genotype, our results are similar to those of Matitaputty et al [27], who reported that, in comparisons, consumers preferred the meat of hybrid ducks to the meat of pure breeds. A significant effect of sex was found for both ages in the sensory analysis. Baeza et al [28] reported that the breast meat of female ducks appeared less tender and less juicy, but had more intense flavour than the meat of males, as observed in the present study. Kapkowska et al [1] stated that the most critical quality factor associated with consumer satisfaction is the meat tenderness. Chartrin et al [29] found higher tenderness scores for meat with higher fat content. This phenomenon could partly explain the higher overall acceptance score of hybrid goose meat compared with CG meat, because higher abdominal fat proportion, which is indicative of the total body fat content, was found in ES. Furthermore, meat tenderness could also be related to muscle fibre size. Generally, a negative correlation exists between the cross-sectional area of muscle fibres and meat tenderness [30].

\section{CONCLUSION}

We conclude that both the hybrid goose ES and the traditional breed CG are able to provide meat of very good quality in general. Our results showed that ES geese reached relatively high meat performance, and therefore are preferable particularly for intensive meat production system, where their high production potential can be fully realized. Moreover, meat of ES was rated better in terms of sensory attributes. For less intensive growth, the CG seems to be suitable for alternative or organic farming. However, due to its favourable nutritional value, the meat of the CG can satisfy requirements of current consumers.

\section{CONFLICT OF INTEREST}

We certify that there is no conflict of interest with any financial organization regarding the material discussed in the manuscript.

\section{ACKNOWLEDGMENTS}

The present study was supported by projects of the Ministry of Agriculture of the Czech Republic (Project NAAR QI101 A164 and Project MZE RO0714).

\section{REFERENCES}

1. Kapkowska E, Gumułka M, Rabsztyn A, Połtowicz K, Andres
K. Comparative study on fattening results of Zatorska and White Koluda geese. Ann Anim Sci 2011;11:207-17.

2. Hamadani H, Khan AA, Salahudin M, Sofi AH, Banday MT. Slaughter and carcass characteristics, sensory attributes and consumer acceptability of geese meat. Indian J Poult Sci 2013; 48:223-7.

3. Saatci M, Tilki M, Kaya I, Kirmizibayrak T. Effects of fattening lenght, feather colour and sex on some traits in native Turkish geese. II. Carcass traits. Arch Geflugelkd 2009;73:61-6.

4. Kirmizibayrak T, Önk K, Ekiz B, et al. Effects of age and sex on meat quality of Turkish Native Geese raised under a freerange system. Kafkas Univ Vet Fak Derg 2011;17:817-23.

5. Okruszek A, Wołoszyn J, Haraf G, Orkusz A, Wereńska M. Chemical composition and amino acid profiles of goose muscles from native Polish breeds. Poult Sci 2013;92:1127-33.

6. Okruszek A, Książkiewicz J, Wołoszyn J, et al. Changes in selected physicochemical parameters of breast muscles of geese from Polish conservation flocks depending on duration of the post slaughter period. Arch Tierz 2008;3:255-65.

7. Le Bihan-Duval E. Genetic variability within and between breeds of poultry technological meat quality. Worlds Poult Sci J 2004;60:331-4.

8. Tilki M, Saatci M, Kirmizibayrak T, Aksoy A. Effect of age on growth and carcass composition of Native Turkish Geese. Arch Geflugelkd 2005;69:77-83.

9. Isguzar $\mathrm{E}$, Pingel $\mathrm{H}$. Growth, carcass composition and nutrient content of meat of different local geese in Isparta region of Turkey. Arch Tierz 2003;46:71-6.

10. Buzała M, Adamski M, Janicki B. Characteristics of performance traits and the quality of meat and fat in Polish oat geese. Worlds Poult Sci J 2014;70:531-42.

11. Wężyk S, Rosiński A, Bielińnka H, Badowski J, Cywa-Benko K. A note on the meat quality of W11 and W33 White Koluda geese strains. Anim Sci Pap Rep 2003;21:191-9.

12. Liu BY, Wang ZY, Yang HM, et al. Influence of rearing system on growth performance, carcass traits, and meat quality of Yangzhou geese. Poult Sci 2011;90:653-9.

13. Geldenhuys G, Hoffman LC, Muller M. Sensory profiling of Egyptian goose (Alopochen aegyptiacus) meat. Food Res Int 2014;64:25-33.

14. CIElab Colour System. Commission International de P'Eclairage. Paris, France: CIE Publication; 1976.

15. AOAC International. Official methods of analysis. 18th Ed, Maryland, USA: AOAC International; 2005.

16. Diemar W. Laboratoriumbuch für den Lebensmittelchemiker (Laboratory Manual for Food Chemists); Dresden und Leipzig, Germany: Theodor Steinkopff Verlag; 1963.

17. Dvorák Z. Nutritional evaluation of meat of fatstock (in Czech). Praha, Czech Republic: Státní nakladatelství technické literatury; 1987.

18. ISO 8586-1. Sensory analysis methodology. General guidance for the selection and training and monitoring of assessors. 
Part 1. Selected assessors. Geneva, Switzerland: International Organisation for Standardisation; 1993.

19. ISO 8589. Sensory analysis. General guidance for the design of test rooms. Geneva, Switzerland: International Organisation for Standardisation; 1988.

20. Tưmová E, Chodová D, Uhlířová L, et al. Relationship between muscle fibre characteristics and meat sensory properties in three nutria (Myocastor coypus) colour types. Czech J Anim Sci 2016;61:217-22.

21. SAS Institute Inc. The SAS System for Windows. Release 9.4. Cary, NC, USA: SAS Institute Inc.; 2013.

22. Abdullah AY, Marwan MM, Maharmeh HO, Maharmeh SK, Ishmais MAA. Effects of strain on performance, and age at slaughter and duration of post-chilling aging on meat quality traits of broiler. Asian-Australas J Anim Sci 2010;23:1645-56.

23. Dransfield E, Sosnicki AA. Relationship between muscle growth and poultry meat quality. Poult Sci 1991;78:743-6.

24. Jassim JM, Riyard KM, Majid HA, Yanzhang G. Evaluation of physical and chemical characteristics of male and female ducks carcasses at different ages. Pak J Nutr 2011;10:182-9.
25. Baeza E, Salichon MR, Marche G, et al. Effects of age and sex on the structural, chemical and technological characteristics of mule duck meat. Br Poult Sci 2000;41:300-7.

26. Maiorano G, Filetti F, Gambacorta M, Ciarlariello A, Cavone C. Effects of rearing system and genotype on intramuscular collagen properties of pigs. Ital J Anim Sci 2003;2:385-7.

27. Matitaputty PR, Wijaya CH, Bansi H, Laudadio V, Tufarelli $\mathrm{V}$. Influence of duck species and cross-breeding on sensory and quality characteristics of Alabio and Cihateup duck meat. CyTA-J Food 2015;13:522-6.

28. Baeza E, Salichon MR, Marche G, Juin H. Effect of sex on growth, technological and organoleptic characteristics of the Muscovy duck breast muscle. Br Poult Sci 1998;39:398-403.

29. Chartrin P, Méteau K, Jin H, et al. Effects of intramuscular fat levels on sensory characteristics of duck breast meat. Poult Sci 2006;85:914-22.

30. Crouse JD, Koohamaraie M, Seideman SD. The relationship of muscle fibre size to tenderness of beef. Meat Sci 1991;30: 295-302. 